\title{
Stimulatory Effect of Pituitary Adenylate Cyclase-Activating Polypeptide on Catecholamine Synthesis in Cultured Bovine Adrenal Chromaffin Cells: Involvements of Tyrosine Hydroxylase Phosphorylation Caused by $\mathrm{Ca}^{2+}$ Influx and cAMP
}

Hitoshi Houchi, Shuichi Hamano, Yutaka Masuda, Yasuko Ishimura, Mami Azuma, Takeshi Ohuchi and Motoo Oka Department of Pharmacology, Tokushima University School of Medicine, 3-18-15 Kuramoto, Tokushima 770, Japan

Received May 2, 1994 Accepted August 5, 1994

\begin{abstract}
In cultured bovine adrenal chromaffin cells, pituitary adenylate cylase-activating polypeptide (PACAP) stimulated $\left[{ }^{14} \mathrm{C}\right]$ catecholamine synthesis from $\left[{ }^{14} \mathrm{C}\right]$ tyrosine (but not from $\left[{ }^{14} \mathrm{C}\right] \mathrm{DOPA}$ ) in a concentration-dependent manner, causing maximal stimulation at $10^{-7} \mathrm{M}$. The stimulatory action of PACAP was not affected by staurosporine (an inhibitor of protein kinase $C$ ) or in the cells in which protein kinase $C$ was down-regulated by prolonged exposure to TPA (an activator of protein kinase C), whereas it was partially attenuated in $\mathrm{Ca}^{2+}$-free medium. PACAP $\left(10^{-7} \mathrm{M}\right)$ increased the formation of $\left[{ }^{3} \mathrm{H}\right]$ inositol phosphates, $\left[\mathrm{Ca}^{2+}\right]_{\mathrm{i}}$ and ${ }^{45} \mathrm{Ca}^{2+}$ uptake as well as cAMP. The peptide also stimulated the phosphorylation of tyrosine hydroxylase, the enzyme catalyzing the rate-limiting step in catecholamine synthesis. Catecholamine synthesis and tyrosine hydroxylase phosphorylation stimulated by the maximal effective concentration of dibutyryl cAMP or high $\mathrm{K}^{+}$, which activates $\mathrm{Ca}^{2+}$ uptake, were further enhanced by PACAP, suggesting that both CAMP- and $\mathrm{Ca}^{2+}$-dependent protein kinases may be involved in the stimulation of tyrosine hydroxylase phosphorylation and catecholamine synthesis caused by PACAP.
\end{abstract}

Keywords: Pituitary adenylate cyclase-activating polypeptide, Catecholamine formation, Tyrosine hydroxylase, Phosphorylation, Chromaffin cell

Pituitary adenylate cyclase-activating polypeptide (PACAP) originally isolated from bovine hypothalamus stimulates adenylate cyclase activation in rat cultured pituitary cells $(1,2)$. In addition to brain, PACAP is widely distributed in other organs such as the testis, gastrointestinal tract and lung (3). The concentration of PACAP is also relatively high in the adrenal gland, in which the peptide stimulated the secretion of catecholamines mainly by the activation of voltage-dependent $\mathrm{Ca}^{2+}$ channels $(4$, 5).

Tyrosine hydroxylase, the rate-limiting enzyme in catecholamine synthesis, is phosphorylated and activated by cAMP/forskolin (an activator of adenylate cyclase), phorbol esters (activators of protein kinase $\mathrm{C}$ ) or the elevation of the intracellular concentration of $\left.\mathrm{Ca}^{2+}\left(\mathrm{Ca}^{2+}\right]_{\mathrm{i}}\right)$ caused by nicotinic receptor stimulation, high $\mathrm{K}^{+}$-induced depolarization or $\mathrm{Ca}^{2+}$ ionophores (6-8).

In bovine adrenal chromaffin cells, the phosphorylation and activation of tyrosine hydroxylase are mediated by cAMP-dependent and $\mathrm{Ca}^{2+} /$ calmodulin-dependent pro- tein kinases/protein kinase $C(6,9,10)$. We have reported the activation and phosphorylation of tyrosine hydroxylase by high $\mathrm{K}^{+}$, cholinergic agonists, dibutyryl cAMP, phorbol esters and bioactive neuropeptides (bradykinin and vasoactive intestinal polypeptide) in adrenal chromaffin cells and pheochromocytoma PC-12 cells (11-14). However, little is known about the effect of PACAP on catecholamine biosynthesis. In the present study, we investigated the effects of PACAP on $\left[{ }^{14} \mathrm{C}\right]$ catecholamine synthesis and phosphorylation of tyrosine hydroxylase in cultured bovine adrenal chromaffin cells.

\section{MATERIALS AND METHODS}

\section{Cell preparation and culture}

Bovine adrenal chromaffin cells were dispersed enzymatically as described previously (15). The cells were plated in $35-\mathrm{mm}$ culture dishes at a density of $2 \times 10^{6}$ cells/dish for standard experiments or on $22 \times 22 \mathrm{~mm}$ cover glasses in $35-\mathrm{mm}$ culture dishes at a density of $1 \times 10^{6}$ cells $/$ dish for 
measuring intracellular calcium. They were maintained for 3-5 days as monolayer cultures in Eagle's basal medium supplemented with $5 \%$ heat-inactivated fetal calf serum, $2 \mathrm{mM}$ glutamine, penicillin (100 units $/ \mathrm{ml}$ ), streptomycin $(100 \mu \mathrm{g} / \mathrm{ml})$, gentamycin $(40 \mu \mathrm{g} / \mathrm{ml})$, fungizone $(2.5 \mu \mathrm{g} / \mathrm{ml})$ and $10 \mu \mathrm{M}$ cytosine arabinoside.

\section{Measurement of catecholamine synthesis}

Catecholamine synthesis was measured as described previously (12). The cells were incubated at $37^{\circ} \mathrm{C}$ for 15 to $45 \mathrm{~min}$ in $1 \mathrm{ml}$ of BSS $(135 \mathrm{mM} \mathrm{NaCl}, 5.6 \mathrm{mM} \mathrm{KCl}, 1.2$

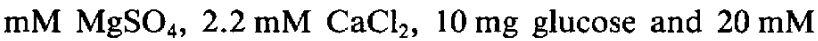
HEPES/NaOH; pH 7.4) containing $20 \mu \mathrm{M} \mathrm{L}-\left[{ }^{14} \mathrm{C}\right]$ tyrosine $(0.5 \mu \mathrm{Ci}) .\left[{ }^{14} \mathrm{C}\right]$ Catecholamine from $\mathrm{L}-\left[{ }^{14} \mathrm{C}\right]$ tyrosine was isolated on aluminium hydroxide, and radioactivity was counted by liquid scintillation spectrometry (16). In some experiments, $\left.\mathrm{L}-{ }^{14} \mathrm{C}\right] \mathrm{DOPA}(50 \mu \mathrm{M}, 0.5 \mu \mathrm{Ci})$ was used as substrate instead of $\mathrm{L}-\left[{ }^{14} \mathrm{C}\right]$ tyrosine. $\left[{ }^{14} \mathrm{C}\right]$ Catecholamine from $\mathrm{L}-\left[{ }^{14} \mathrm{C}\right] \mathrm{DOPA}$ was measured by ionexchange chromatography on a Duolite C-25 column (16).

\section{Measurement of inositol phosphates formation}

Cells were incubated for $48 \mathrm{hr}$ with $5 \mu \mathrm{Ci} / \mathrm{ml}\left[{ }^{3} \mathrm{H}\right]$ inositol in inositol-free Dulbecco's modified Eagle's serum-free medium. Then the cells were preincubated in BSS containing $10 \mathrm{mM} \mathrm{LiCl}$ for $10 \mathrm{~min}$ at $37^{\circ} \mathrm{C}$ and incubated for $10 \mathrm{~min}$ with or without test compounds. The reaction was stopped by addition of ice-cold trichloroacetic acid solution $\left(10 \%\right.$, final concentration). $\left[{ }^{3} \mathrm{H}\right]$ Inositol phosphates were measured by anion-exchange chromatography as described previously $(17,18)$.

\section{Measurement of intracellular calcium with fura-2}

The $\left[\mathrm{Ca}^{2+}\right]_{\mathrm{i}}$ in single chromaffin cells was measured by the fluorescent $\mathrm{Ca}^{2+}$ indicator fura-2. The cells, which were cultured on cover glasses, were incubated at $37^{\circ} \mathrm{C}$ for $30 \mathrm{~min}$ in $1 \mathrm{ml}$ of BSS containing $2 \mu \mathrm{M}$ fura-2/acetoxy methyl ester. Then the cells on the cover glasses were transferred to a small incubation bath (approx. $0.5 \mathrm{ml}$ ) on the platform of a microscope. Fluorescence was measured in a single chromaffin cell on the cover glass using a fluorescence spectromicroscope (excitation, $340 / 380 \mathrm{~nm}$; emission, $510 \mathrm{~nm})$. The $\left[\mathrm{Ca}^{2+}\right]_{i}$ was calculated by the previously decribed equation (19).

\section{Measurement of ${ }^{45} \mathrm{Ca}^{2+}$ uptake}

Incubation medium containing $6 \mu \mathrm{Ci}$ of ${ }^{45} \mathrm{Ca}^{2+}$ was added to the cells. After incubation, the dishes were immediately chilled on ice and washed three times with ice-cold $\mathrm{Ca}^{2+}$-free BSS. The ${ }^{45} \mathrm{Ca}^{2+}$ taken up into the cells was extracted with $1 \%$ Triton $X-100$ and counted in a liquid scintillation counter.

\section{Measurement of cyclic AMP levels}

3-Isobutyl-1-methylxanthine $(0.5 \mathrm{mM})$ was added to all tissue culture dishes to prevent the breakdown of cAMP. The cells were scraped from the dishes into $10 \%$ trichloroacetic acid solution, and the samples were centrifuged to remove denatured proteins. The supernatant fractions were extracted by ethyl ether, and cAMP was isolated from the solutions on Dowex- 50 columns by the method of Su et al. (20). The cAMP level was measured by enzyme immunoassay with an Amersham cAMP enzyme immunoassay system kit.

Measurement of phosphorylation of tyrosine hydroxylase Phosphorylation of tyrosine hydroxylase in the cells was measured as described previously (14). The cells were incubated with $\left[{ }^{32} \mathrm{P}\right]$ phosphate (carrier-free; $1.5 \mathrm{mCi} / \mathrm{ml}$ ) for $60 \mathrm{~min}$ at $37^{\circ} \mathrm{C}$ in BSS buffer, washed with prewarmed BSS $\left(37^{\circ} \mathrm{C}\right)$ and incubated with or without test compounds for $30 \mathrm{~min}$. The phosphorylated tyrosine hydroxylase was separated by antiserum specific for tyrosine hydroxylase. Then, the phosphorylated tyrosine hydroxylase was applied to SDS-polyacrylamide slab gel as described previously $(21,22)$. After electrophoresis, the $\left[{ }^{32} \mathrm{P}\right]$ phosphate incorporated into tyrosine hydroxylase was analyzed by measuring the density of the autoradiographic band on the gel corresponding to the purified $\left[{ }^{32} \mathrm{P}\right]$ tyrosine hydroxylase standard and by cutting out this band and determining its radioactivity by Cerenkov analysis.

\section{Statistical analyses}

The results are expressed as the mean \pm standard error (S.E.). Statistical differences between two groups were determined by Student's $t$-test for unpaired observations and analyses of variance, respectively.

\section{Chemicals}

L- $\left[{ }^{14} \mathrm{C}\right]$ Tyrosine, ${ }^{45} \mathrm{CaCl}_{2}$ and a cyclic AMP assay kit were obtained from Amersham Corp. (Tokyo). $\left.{ }^{32} \mathrm{P}\right]-$ Phosphorus and myo- $\left[2-{ }^{3} \mathrm{H}\right]$ inositol were obtained from New England Nuclear Corp. (Tokyo). Pituitary adenylate cyclase-activating polypeptide $_{1-38}$ and bradykinin were obtained from the Peptide Institute (Osaka). Dibutyryl cAMP and 12-O-tetradecanoyl phorbol 13-acetate (TPA) were from Sigma Chemical Co. (St. Louis, MO, USA), and forskolin and staurosporine were from CalbiochemBehring (Tokyo). Other chemicals used were commercial products of reagent grade.

\section{RESULTS}

\section{Effect of PACAP on catecholamine synthesis}

Figure 1 shows the synthesis of $\left[{ }^{14} \mathrm{C}\right]$ catecholamine 
from $\left[{ }^{14} \mathrm{C}\right]$ tyrosine caused by various concentrations of PACAP. PACAP, at concentrations between of $10^{-9}$ and

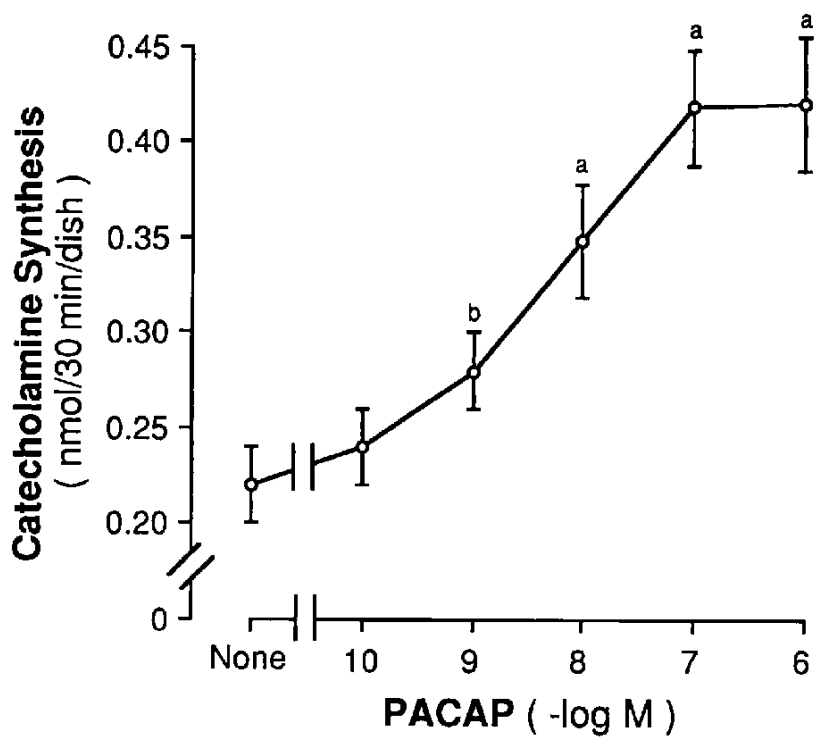

Fig. 1. Effects of various concentrations of PACAP on catecholamine synthesis in cultured bovine adrenal chromaffin cells. Cells were incubated at $37^{\circ} \mathrm{C}$ for $30 \mathrm{~min}$ in the presence or absence of various concentrations of PACAP. Catecholamine synthesis was determined as described in Materials and Methods. Data are means \pm S.E. for 4-6 separate experiments. $a$ and $b$, Significantly more than the value without $\mathrm{PACAP}(\mathrm{P}<0.01$ and $\mathrm{P}<0.05$, respectively).

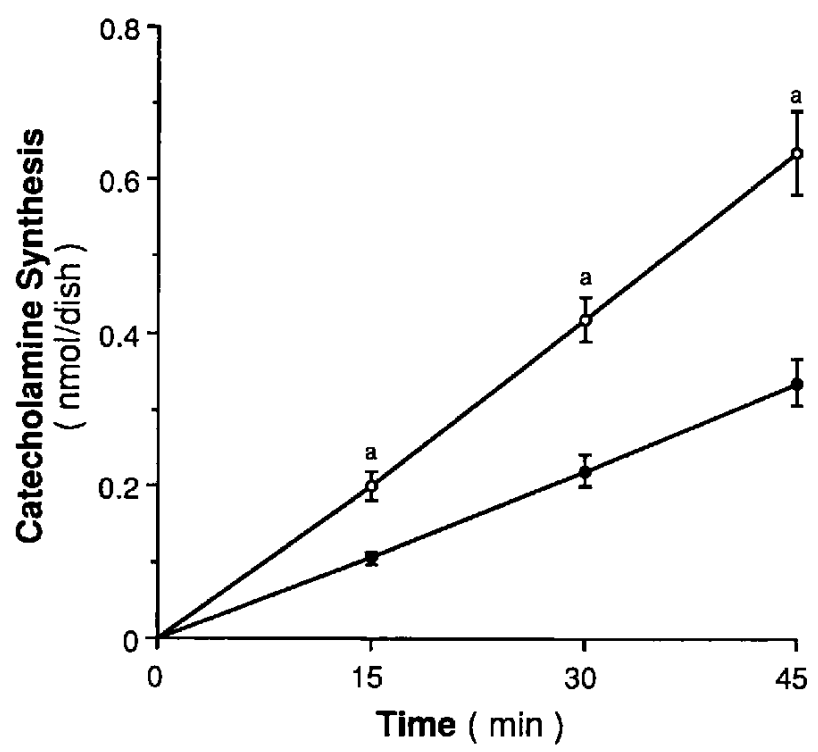

Fig. 2. Time course of PACAP-stimulated catecholamine synthesis in cultured bovine adrenal chromaffin cells. Cells were incubated at $37^{\circ} \mathrm{C}$ for the indicated times in the presence (open circles) or absence (closed circles) of $10^{-7} \mathrm{M}$ PACAP. Catecholamine synthesis was determined as described in Materials and Methods. Data are means \pm S.E. for 4-6 separate experiments. a, Significantly more than the respective value in the absence of PACAP $(P<0.01)$.
$10^{-7} \mathrm{M}$, stimulated ${ }^{\left[{ }^{14} \mathrm{C}\right] \text { catecholamine synthesis in a con- }}$ centration-dependent manner; its maximal effect $(190 \%$ increase) occurred at $10^{-7} \mathrm{M}$, and its half-maximal effective concentration $\left(\mathrm{EC}_{50}\right)$ was approximately $5 \times 10^{-9} \mathrm{M}$. PACAP, however, failed to stimulate $\left[{ }^{14} \mathrm{C}\right]$ catecholamine synthesis from $\left[{ }^{14} \mathrm{C}\right] D O P A$ (control, $3.7 \pm 0.4 \mathrm{nmol} / 30 \mathrm{~min}$ /dish; PACAP-treated cells, $3.9 \pm 0.4 \mathrm{nmol} / 30 \mathrm{~min} / \mathrm{dish}$ ), suggesting that PACAP increased the conversion of tyrosine to DOPA catalyzed by tyrosine hydroxylase, the rate-limiting step in catecholamine biosynthesis. As shown in Fig. 2, the stimulation of $\left[{ }^{14} \mathrm{C}\right]$ catecholamine synthesis by PACAP $\left(10^{-7} \mathrm{M}\right)$ proceeded linearly with the duration of incubation for at least $45 \mathrm{~min}$.

\section{Effect of calcium ion on PACAP-stimulated catechol- amine synthesis}

To know the stimulatory mode of PACAP in $\left[{ }^{14} \mathrm{C}\right] \mathrm{cat}-$ echolamine synthesis, we examined whether the effect of PACAP would be attenuated in calcium-free medium. As shown in Fig. 3, the stimulatory effect of PACAP was diminished by $43 \%$ in calcium-free medium. We then examined the possible involvement of protein kinase $\mathrm{C}$ in

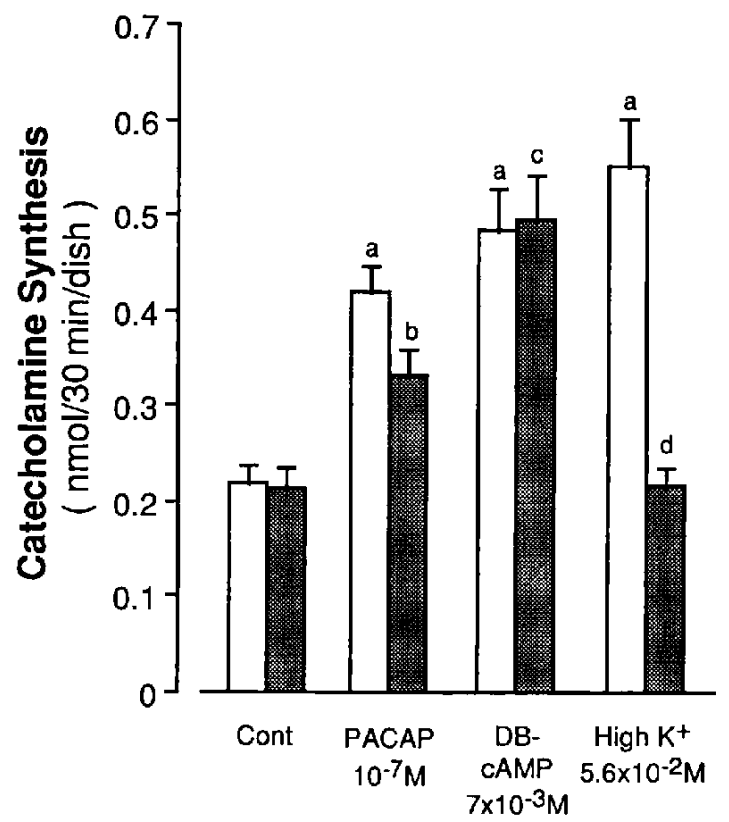

Fig. 3. Effects of removal of extracellular $\mathrm{Ca}^{2+}$ on PACAP-, dibutyryl cAMP (DB-cAMP)- and high $\mathrm{K}^{+}$-stimulated catecholamine synthesis in cultured bovine adrenal chromaffin cells. Cells were incubated at $37^{\circ} \mathrm{C}$ for $30 \mathrm{~min}$ in the presence or absence of $10^{-7}$ $\mathrm{M}$ PACAP, $7 \times 10^{-3} \mathrm{M}$ DB-cAMP or $5.6 \times 10^{-2} \mathrm{M}_{\text {high } \mathrm{K}^{+} \text {with }}$ (open columns) or without (hatched columns) extracellular $\mathrm{Ca}^{2+}$. Catecholamine synthesis was determined as described in Materials and Methods. Data are means \pm S.E. for $4-6$ separate experiments. Significance of differences at $\mathbf{P}<0.01$ : $a$, more than control value; $b$, less than PACAP-stimulated catecholamine synthesis; $c$, not significantly different from that on DB-cAMP stimulation; d, less than that on high $\mathbf{K}^{+}$stimulation. 
PACAP-stimulated $\left[{ }^{14} \mathrm{C}\right]$ catecholamine synthesis. The stimulatory effect of PACAP was not influenced by staurosporine $\left(10^{-6} \mathrm{M}\right)$, an inhibitor of protein kinase $C$, and by deprivation of protein kinase $\mathrm{C}$ from the cells by prolonged $(24 \mathrm{hr})$ exposure to relatively high concentrations $\left(10^{-6} \mathrm{M}\right)$ of TPA (data not shown; see also refs. 23-26). It seems that the stimulation of catecholamine synthesis following PACAP treatment is dependent, in part, on extracellular calcium, but independent of protein kinase $\mathrm{C}$. High $\mathrm{K}^{+}$and dibutyryl cAMP also stimulated catecholamine synthesis, the effect of the former (but not the latter) being absolutely dependent on extracellular calcium.

Inositol 1,4,5-trisphosphate $\left(\mathrm{IP}_{3}\right)$ produced by the stimulation of phospholipase $\mathrm{C}$ is reported to mobilize $\mathrm{Ca}^{2+}$ from the intracellular storage pools (27). Figure 4 shows the effects of PACAP on the level of inositol phosphates and the effects of $\left[\mathrm{Ca}^{2+}\right]_{\mathrm{i}}$. PACAP $\left(10^{-7} \mathrm{M}\right)$ increased $\left[{ }^{3} \mathrm{H}\right]$ inositol phosphates by $141 \%$ over the control. Bradykinin $\left(10^{-6} \mathrm{M}\right)$, which is known to increase $\mathrm{IP}_{3}$ in the adrenal chromaffin cells (28), elevated $\left[{ }^{3} \mathrm{H}\right]$ inositol phosphates by $356 \%$. In contrast, high $\mathrm{K}^{+}\left(5.6 \times 10^{-2} \mathrm{M}\right)$ did not significantly increase $\left[{ }^{3} \mathrm{H}\right]$ inositol phosphates. PACAP $\left(10^{-7} \mathrm{M}\right)$ increased $\left[\mathrm{Ca}^{2+}\right]_{\mathrm{i}}$ in a biphasic manner, and $\left[\mathrm{Ca}^{2+}\right]_{\mathrm{i}}$ reached the levels of 238 and $618 \mathrm{nM}$ at the initial rapid and a subsequent sustained phase, respectively. Bradykinin increased $\left[\mathrm{Ca}^{2+}\right]_{\mathrm{i}}$ to $430 \mathrm{nM}$ as a consequence of $\mathrm{IP}_{3}$-stimulated release of $\mathrm{Ca}^{2+}$ from intracellular pools. High $\mathrm{K}^{+}$increased $\left[\mathrm{Ca}^{2+}\right]_{\mathrm{i}}$ to $890 \mathrm{nM}$ through the activation of voltage-dependent calcium channels. Since PACAP induced a biphasic rise in $\left[\mathrm{Ca}^{2+}\right]_{i}$, we examined the effect of PACAP on ${ }^{45} \mathrm{Ca}^{2+}$ uptake into adrenal chromaffin cells. As shown in Fig. 5, PACAP $\left(10^{-7} \mathrm{M}\right)$ and high $\mathrm{K}^{+}\left(5.6 \times 10^{-2} \mathrm{M}\right)$ increased ${ }^{45} \mathrm{Ca}^{2+}$ uptake by $102 \%$ and $149 \%$, respectively, whereas bradykinin $\left(10^{-6} \mathrm{M}\right)$ had only a slight effect on ${ }^{45} \mathrm{Ca}^{2+}$ uptake. These data, therefore, suggest that PACAP stimulates the release of $\mathrm{Ca}^{2+}$ from intracellular pools and the uptake of extracellular $\mathrm{Ca}^{2+}$ on adrenal chromaffin cells.

\section{Effect of PACAP on CAMP formation}

Figure 6 illustrates the effects of PACAP, forskolin
(A)

(B)

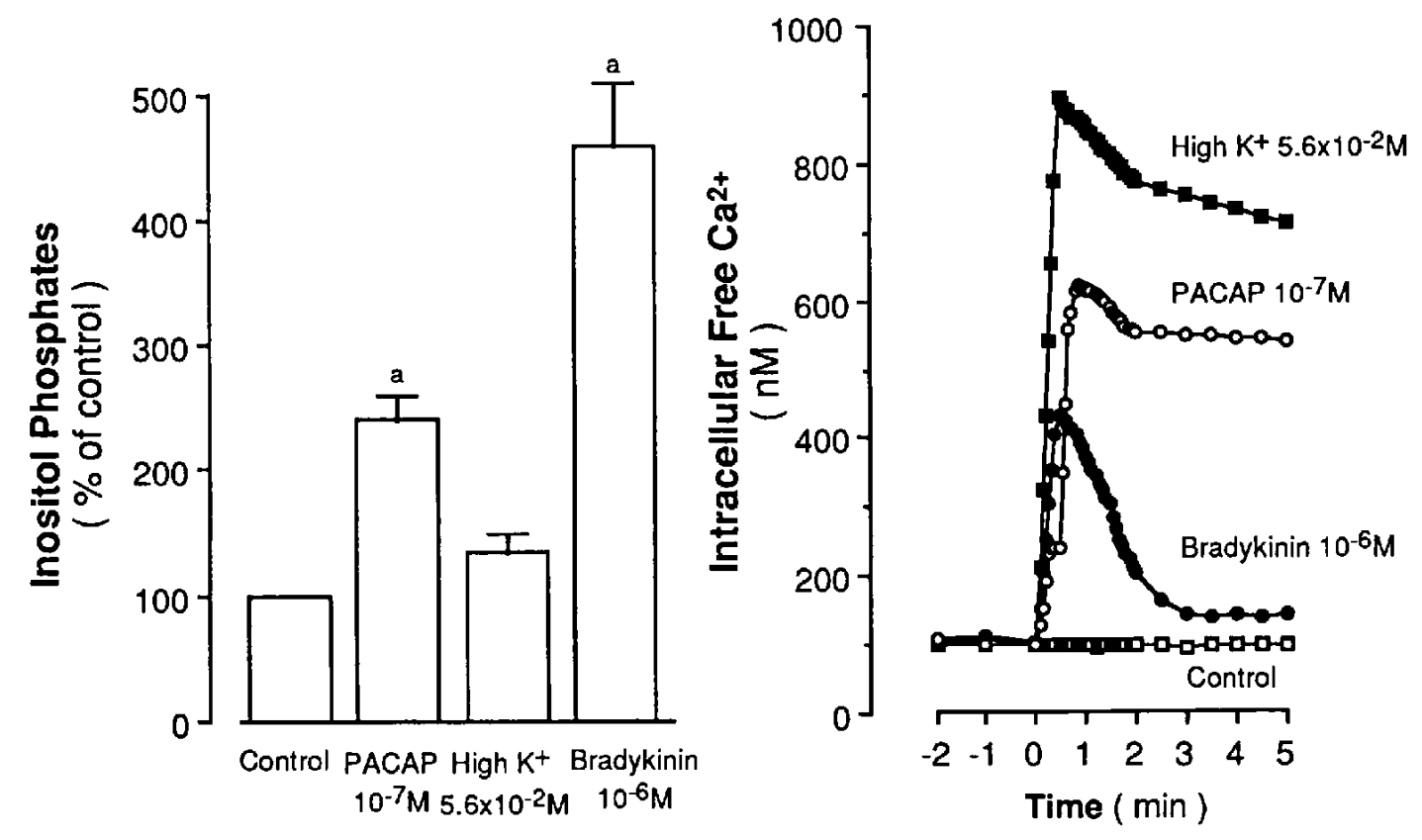

Fig. 4. Effects of PACAP, high $\mathrm{K}^{+}$and bradykinin on inositol phosphates level and $\left[\mathrm{Ca}^{2+}\right]_{i}$ in cultured bovine adrenal chromaffin cells. A, Cells were maintained for $48 \mathrm{hr}$ with $5 \mu \mathrm{Ci} / \mathrm{ml}\left[{ }^{3} \mathrm{H}\right]$ inositol in inositol-free medium without serum. They were then preincubated at $37^{\circ} \mathrm{C}$ for $10 \mathrm{~min}$ with $10 \mathrm{mM} \mathrm{LiCl}$ and incubated at $37^{\circ} \mathrm{C}$ for $10 \mathrm{~min}$ with or without $10^{-7} \mathrm{M} \mathrm{PACAP}$, $5.6 \times 10^{-2} \mathrm{M}$ high $\mathrm{K}^{+}$or $10^{-6} \mathrm{M}$ bradykinin with $10 \mathrm{mM} \mathrm{LiCl}$. Accumulation of $\left[{ }^{3} \mathrm{H}\right]$ inositol phosphates was assayed as described in Materials and Methods. Data are means \pm S.E. for 3 separate experiments. a, Significantly more than the control value $(\mathrm{P}<0.01)$. B, Cells were incubated at $37^{\circ} \mathrm{C}$ for $30 \mathrm{~min}$ with fura-2/acetoxy methyl ester. The $10^{-7} \mathrm{M}$ PACAP (open circles), $5.6 \times 10^{-2} \mathrm{M}$ high $\mathrm{K}^{+}$(closed squares) or $10^{-6} \mathrm{M}$ bradykinin (closed circles) was added at 0 time. Control values are shown by open squares. $\left[\mathrm{Ca}^{2+}\right]_{i}$ was determined as described in Materials and Methods. Data are means for 4 separate experiments. The maximal standard error was $\pm 9.6 \%$. All peaks of fura-2 fluorescence with test compounds were significantly greater than the control level $(\mathbf{P}<\mathbf{0 . 0 1})$. 


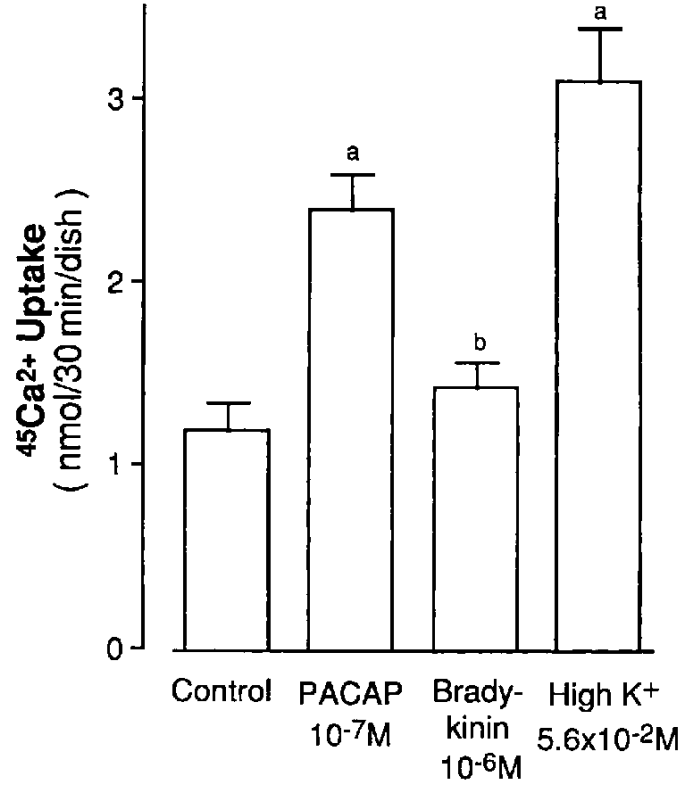

Fig. 5. Effects of PACAP, bradykinin and high $\mathrm{K}^{+}$on ${ }^{45} \mathrm{Ca}^{2+}$ uptake by cultured bovine adrenal chromaffin cells. Cells were incubated at $37^{\circ} \mathrm{C}$ for $30 \mathrm{~min}$ in the presence or absence of $10^{-7} \mathrm{M}$ PACAP, $10^{-6} \mathrm{M}$ bradykinin or $5.6 \times 10^{-2} \mathrm{M}$ high $\mathrm{K}^{+} .{ }^{45} \mathrm{Ca}^{2+}$ uptake into the cells was determined as described in Materials and Methods. Data are means \pm S.E. for 4-6 separate experiments, $a$ and $b$, Significantly greater than the control value $(P<0.01$ and $<0.05$, respectively).

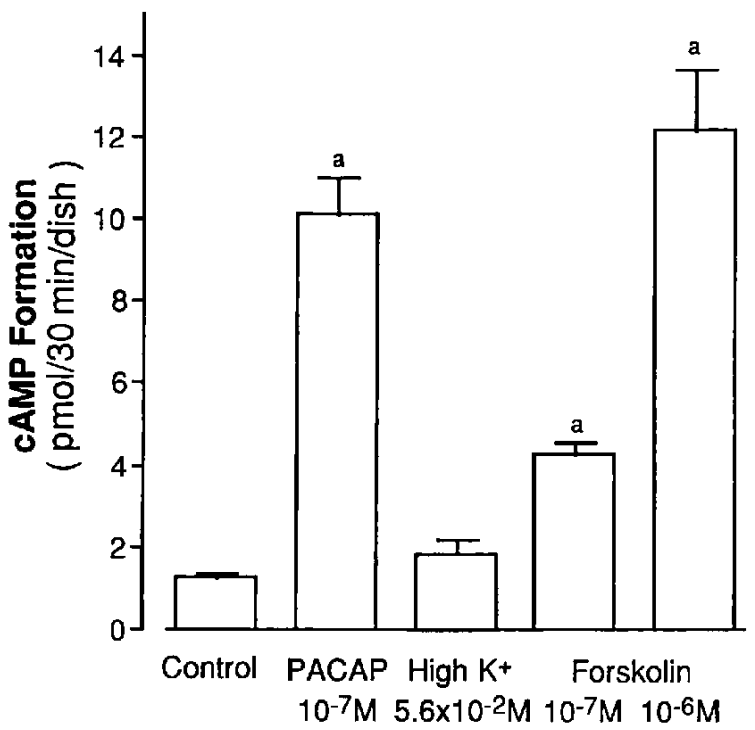

Fig. 6. Effects of PACAP, high $\mathrm{K}^{+}$and forskolin on cAMP formation in cultured bovine adrenal chromaffin cells. Cells were preincubated at $37^{\circ} \mathrm{C}$ for $10 \mathrm{~min}$ with $5 \times 10^{-4} \mathrm{M}$ 3-isobutyl-1-methylxanthine (IBMX) and then incubated at $37^{\circ} \mathrm{C}$ for $30 \mathrm{~min}$ with or without $10^{-7} \mathrm{M}$ PACAP, $5.6 \times 10^{-2} \mathrm{M}$ high $\mathrm{K}^{+}$or $10^{-7} \mathrm{M}$ or $10^{-6} \mathrm{M}$ forskolin with IBMX. cAMP level in the cells was determined as described in Materials and Methods. Data are means \pm S.E. for 3 separate experiments. a, Significantly greater than the control value $(\mathrm{P}<0.01)$.

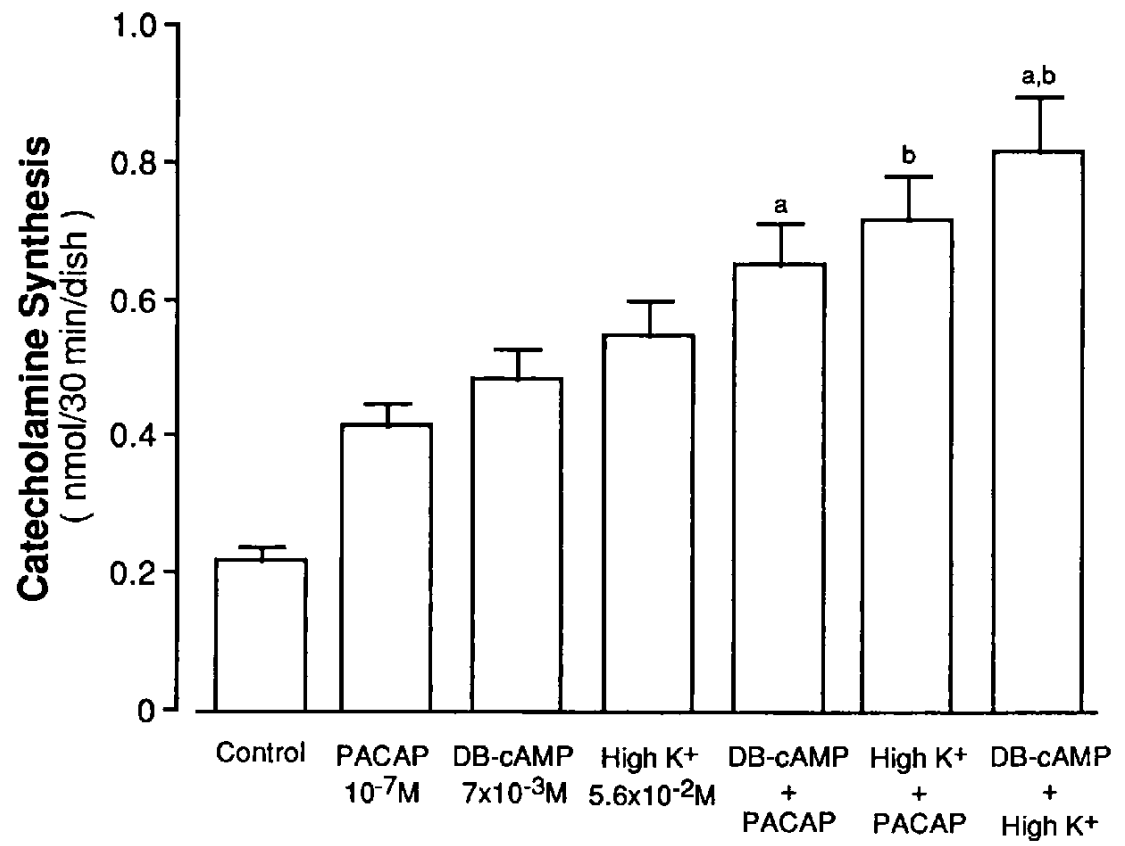

Fig. 7. Effects of PACAP, dibutyryl cAMP (DB-cAMP) and high $\mathrm{K}^{+}$on catecholamine synthesis in cultured bovine adrenal chromaffin cells. Cells were incubated at $37^{\circ} \mathrm{C}$ for $30 \mathrm{~min}$ in the presence or absence of $10^{-7} \mathrm{M}$ PACAP, $7 \times 10^{-3} \mathrm{M} \mathrm{DB}-\mathrm{cAMP}$ or $5.6 \times 10^{-2} \mathrm{M}$ high $\mathrm{K}^{+}$. Catecholamine synthesis was determined as described in Materials and Methods. Data are means \pm S.E. for 4 separate experiments. All test compounds significantly increased catecholamine synthesis over the control value. a, Significantly greater than DB-cAMP-stimulated catecholamine synthesis $(P<0.01)$; $b$, significantly greater than high $\mathrm{K}^{+}$-stimulated catecholamine synthesis $(\mathrm{P}<0.01)$. 
(an activator of adenylate cyclase) and high $\mathrm{K}^{+}$on cAMP level. PACAP increased cAMP to $709 \%$ of the control, which was comparable to that due to forskolin, while high $\mathrm{K}^{+}$had no effect on cAMP. The concentrations of PACAP on cAMP formation were similar to those of ${ }^{45} \mathrm{Ca}^{2+}$ uptake and $\left[{ }^{14} \mathrm{C}\right]$ catecholamine synthesis in adrenal chromaffin cells (data not shown).

Effects of PACAP, dibutyryl cAMP and high $K^{+}$on catecholamine synthesis

Dibutyryl cAMP and high $\mathrm{K}^{+}$are reported to increase catecholamine synthesis by the activation of tyrosine hydroxylase through cAMP-dependent protein kinase and calcium-dependent protein kinases, respectively $(6$, 29). As shown in Fig. 7 , dibutyryl cAMP $\left(7 \times 10^{-3} \mathrm{M}\right)$ or high $\mathrm{K}^{+}\left(5.6 \times 10^{-2} \mathrm{M}\right)$, by itself, increased catecholamine synthesis by $120 \%$ or $150 \%$, and their simultaneous application caused an additive increase $(276 \%)$ in catecholamine synthesis. Although PACAP $\left(10^{-7} \mathrm{M}\right)$, by itself, increased catecholamine synthesis by $90 \%$ and also augmented the stimulatory effects of dibutyryl cAMP and high $\mathrm{K}^{+}$from $120 \%$ and $152 \%$ to $196 \%$ and $228 \%$ respectively, the stimulatory effect of PACAP in combination of dibutyryl cAMP or high $\mathrm{K}^{+}$was less than additive. Since the concentrations of PACAP, dibutyryl cAMP and high $\mathrm{K}^{+}$used were those causing the maximal stimulation of catecholamine synthesis $(11,12,14)$, our data suggest that PACAP-induced catecholamine synthesis may be mediated by both cAMP-dependent and calcium-dependent protein kinases.

Effect of PACAP, dibutyryl cAMP and high $\mathrm{K}^{+}$on phosphorylation of tyrosine hydroxylase

As shown in Fig. 8, phosphorylation of tyrosine hydroxylase was stimulated 2.5 -fold in the cells treated with PACAP $\left(10^{-7} \mathrm{M}\right)$. In addition, PACAP further enhanced the stimulatory effects of dibutyryl cAMP $(7 \times$ $\left.10^{-3} \mathrm{M}\right)$ and high $\mathrm{K}^{+}\left(5.6 \times 10^{-2} \mathrm{M}\right)$ from 2.2- and 3.6fold to 3.3- and 4.1-fold, respectively.

\section{Phosphorylation} ( $\%$ of control)

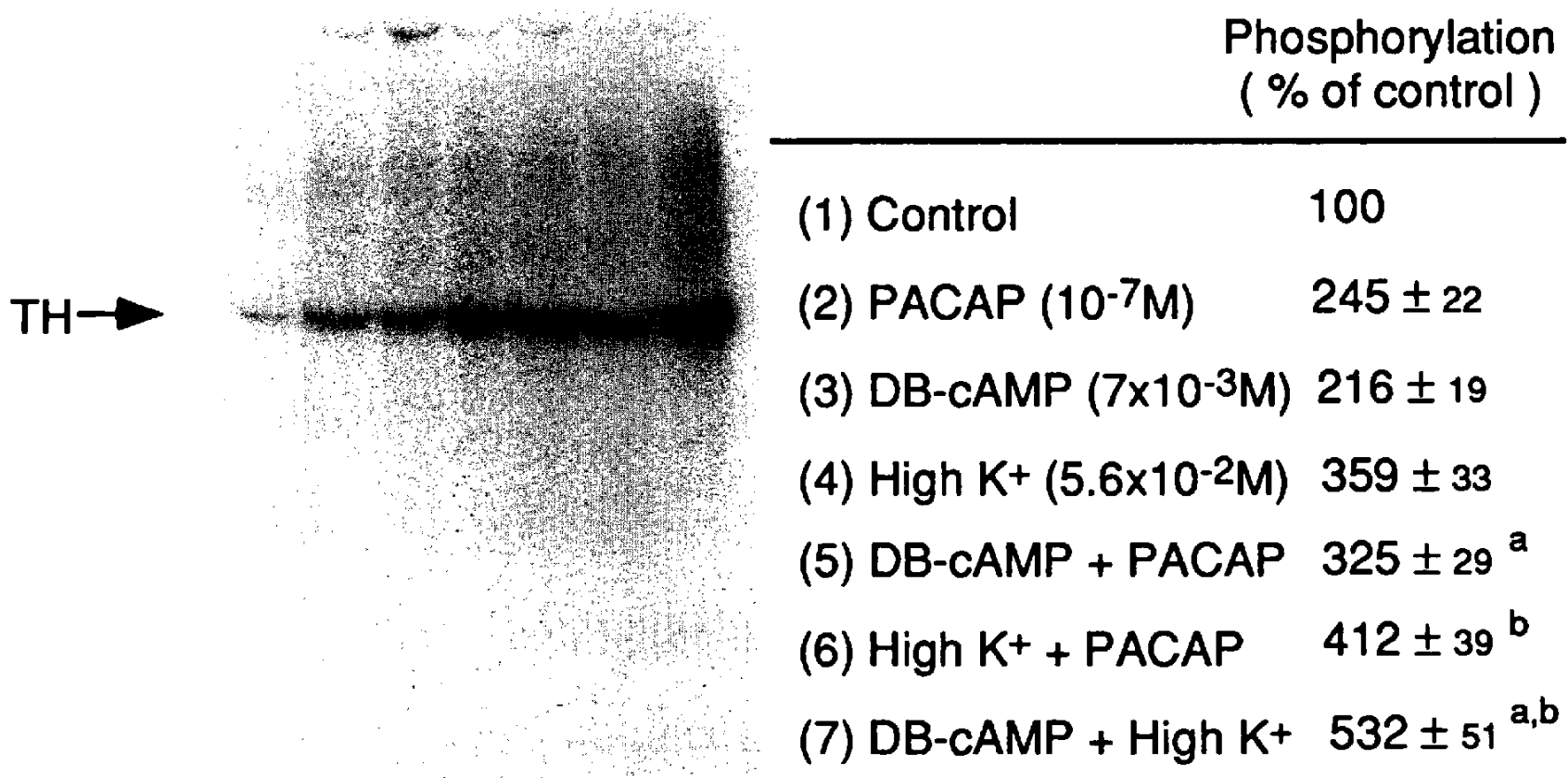

Fig. 8. Effects of PACAP, dibutyryl cAMP (DB-cAMP) and high $\mathrm{K}^{-}$on phosphorylation of tyrosine hydroxylase in cultured bovine adrenal chromaffin cells. Cells were incubated at $37^{\circ} \mathrm{C}$ for $30 \mathrm{~min}$ in the presence or absence of $10^{-7} \mathrm{M} \mathrm{PACAP}, 7 \times 10^{-3}$ M DB-cAMP or $5.6 \times 10^{-2} \mathrm{M}$ high $\mathrm{K}^{+}$. Tyrosine hydroxylase phosphorylation was determined as described in Materials and Methods. Data are means \pm S.E. for 3 separate experiments. All test compounds significantly increased tyrosine hydroxylase phosphorylation over the control value. a, Significantly greater than the value with DB-cAMP $(P<0.01)$; $b$, significantly greater than the value with high $\mathrm{K}^{-}(\mathrm{P}<0.01)$. 


\section{DISCUSSION}

In cultured bovine adrenal chromaffin cells, we examined for the first time the mechanism(s) by which PACAP stimulates catecholamine synthesis. PACAP increased $\left[{ }^{14} \mathrm{C}\right]$ catecholamine synthesis from $\left[{ }^{14} \mathrm{C}\right]$ tyrosine (but not from $\left.\left[{ }^{14} \mathrm{C}\right] \mathrm{DOPA}\right)$ in a concentration-dependent manner, suggesting that PACAP increases the conversion of tyrosine to DOPA, a rate-limiting step in the biosynthesis of catecholamines.

We have previously found that the synthesis of catecholamines is increased in the cells treated with phorbol esters in a protein kinase C-related process(es) (12). Upon the breakdown of phosphatidyl inositol 4,5-bisphosphate $\left(\mathrm{PIP}_{2}\right)$ by phospholipase $\mathrm{C}(30)$, diacylglycerol, a physiological activator of protein kinase $\mathrm{C}$ that increases the affinity of the enzyme for $\mathrm{Ca}^{2+}(30,31)$, is produced along with $\mathrm{IP}_{3}$ that mobilizes $\mathrm{Ca}^{2+}$ from the endoplasmic reticulum (27). Our previous (14) and present studies showed that bradykinin $\left(10^{-6} \mathrm{M}\right)$ increased the formation of inositol phosphates by 4.6 -fold and elevated $\left[\mathrm{Ca}^{2+}\right]_{i}$ to 430 nM. PACAP, on the other hand, induced modest increases in inositol phosphates (2.4-fold) and $\left[\mathrm{Ca}^{2+}\right]_{\mathrm{i}}(238$ nM) (Fig. 4). Moreover, the stimulatory effect of PACAP on $\left[{ }^{14} \mathrm{C}\right]$ catecholamine synthesis was not inhibited by staurosporine or in the cells deprived of protein kinase $C$ (data not shown). These results suggest that protein kinase $\mathrm{C}$ does not play a major role in the PACAP-induced catecholamine synthesis.

The activation of tyrosine hydroxylase by $\left[\mathrm{Ca}^{2+}\right]_{i}$ is thought to be mediated by calcium/calmodulin-dependent protein kinase in a number of in vitro and in situ systems $(6,32-34)$. In adrenal chromaffin cells, cAMP also stimulates the synthesis of catecholamines through cAMP-dependent protein kinase $(6,9,11)$. In the present study, PACAP increased $\left[\mathrm{Ca}^{2+}\right]_{\mathrm{i}}$ to $618 \mathrm{nM}$ at a second sustained phase (Fig. 4) and increased $\mathrm{Ca}^{2+}$ uptake twofold (Fig. 5). The level of cAMP was also elevated eightfold by PACAP, which was comparable to the effect of forskolin (tenfold) (Fig. 6). We then examined whether PACAP stimulated catecholamine synthesis through either a cAMP- or $\mathrm{Ca}^{2+}$-dependent process. The increased synthesis of catecholamines caused by the maximal effective concentration of either dibutyryl cAMP or high $\mathrm{K}^{+}$was further enhanced by PACAP, suggesting that the effect of PACAP may be mediated through a $\mathrm{Ca}^{2+}$ /calmodulin- and cAMP-dependent process(es).

A previous study indicated (5) that PACAP-induced catecholamine secretion from cultured porcine adrenal chromaffin cells was inhibited by voltage-dependent $\mathrm{Ca}^{2+}$ channel blockers nicardipine and methoxyverapamil. Therefore, the increase in $\mathrm{Ca}^{2+}$ uptake into adrenal chromaffin cells caused by PACAP (Fig. 5) may be mediated by stimulation of voltage-dependent $\mathrm{Ca}^{2+}$ channels.

Since the phosphorylation of tyrosine hydroxylase results in its activation (6), we examined whether PACAP would stimulate the phosphorylation of tyrosine hydroxylase. Although PACAP itself increased the phosphorylation of tyrosine hydroxylase, the peptide also enhanced the phosphorylation of tyrosine hydroxylase caused by either dibutyryl cAMP or high $\mathrm{K}^{+}$. Phosphopeptide analysis of tyrosine hydroxylase in $\mathrm{PC} 12$ cells has demonstrated that ${ }^{32} \mathrm{P}$ incorporation into three distinct phosphopeptides are stimulated by $\mathrm{Ca}^{2+} /$ calmodulin-dependent, cAMP-dependent protein kinases and protein kinase $\mathrm{C}$, respectively $(14,22,29)$. Thus, PACAP may stimulate the synthesis of catecholamines by phosphorylation and activation of tyrosine hydroxylase through $\mathrm{Ca}^{2+} /$ calmodulin-dependent and cAMP-dependent protein kinases also in adrenal chromaffin cells.

\section{Acknowledgment}

The authors thank Mr. Masayuki Shono for measurement of intracellular free calcium levels.

\section{REFERENCES}

1 Miyata A, Arimura A, Dahl RR, Minamino N, Uehara A, Jiang L, Culler DM and Coy DH: Isolation of a novel 38 residuehypothalamic polypeptide which stimulates adenylate cyclase in pituitary cells. Biochem Biophys Res Commun 164, 567-574 (1989)

2 Miyata A, Jiang L, Dahl RR, Kitada C, Kubo K, Fujino M, Minamino $\mathrm{N}$ and Arimura $\mathrm{A}$ : Isolation of a neuropeptide corresponding to the $\mathrm{N}$-terminal 27 residues of the pituitary adenylate cyclase activating polypeptide with 38 residues (PACAP38). Biochem Biophys Res Commun 170, 643-648 (1990)

3 Arimura A, Somogyvari-Vigh A, Miyata A, Mizuno K, Coy DH and Kitada C: Tissue distribution of PACAP as determined by RIA. Endocrinology 129, 2787-2789 (1991)

4 Watanabe T, Masuo Y, Matsumoto H, Suzuki N, Ohtaki T, Masuda Y, Kitada C, Tsuda M and Fujino M: Pituitary adenylate cyclase activating polypeptide provokes cultured rat chromaffin cells to secrete adrenaline. Biochem Biophys Res Commun 182, 403-411 (1992)

5 Isobe $\mathrm{K}$, Nakai $\mathrm{T}$ and Takuwa $\mathrm{Y}: \mathrm{Ca}^{2+}$-dependent stimulatory effect of pituitary adenylate cyclase-activating polypeptide on catecholamine secretion from cultured porcine adrenal medullary chromaffin cells. Endocrinology 132, 1757 - 1765 (1993)

6 Masserano JM, Vulliet PR, Tank AW and Weiner N: The role of tyrosine hydroxylase in the regulation of catecholamine synthesis. In Handbook of Experimental Pharmacology, Vol 90/II, Catecholamines, Edited by Trendelenburg $U$ and Weiner N, pp 427-469, Springer, Berlin (1990)

7 Meligeni JA, Haycock JW, Bennett WF and Waymire JC: Phosphorylation and activation of tyrosine hydroxylase mediate the cAMP-induced increase in catecholamine biosynthesis in adrenal chromaffin cells. J Biol Chem 257, 12632 - 12640 (1982)

8 Pocotte SL and Holz RW: Effects of phorbol ester on tyrosine hydroxylase phosphorylation and activation in cultured bovine adrenal chromaffin cells. J Biol Chem 261, 1873-1877 (1986) 
9 Vulliet PR, Woodgett JR and Cohen P: Phosphorylation of tyrosine hydroxylase by calmodulin-dependent multiprotein kinase. J Biol Chem 259, 13680-13683 (1984)

10 Griffith LC and Schulman $\mathrm{H}$ : The multifunctional $\mathrm{Ca}^{2+}$ /calmodulin-dependent protein kinase mediates $\mathrm{Ca}^{2+}$-dependent phosphorylation of tyrosine hydroxylase. J Biol Chem 263, 9542-9549 (1988)

11 Houchi $H$, Nakagawa $H$, Oka $M$, Watanabe J, Isosaki $M$ and Ohuchi T: Increase in cyclic AMP level and stimulation of catecholamine synthesis in isolated bovine adrenal medullary cells caused by forskolin. Jpn J Pharmacol 36, 97-99 (1984)

12 Houchi $\mathrm{H}$, Nakanishi A, Uddin MM, Ohuchi T and Oka M: Phorbol ester stimulates catecholamine synthesis in isolated bovine adrenal medullary cells. FEBS Lett 188, 205-208 (1985)

13 Houchi H, Oka M, Misbahuddin M, Morita K and Nakanishi A: Stimulation by vasoactive intestinal polypeptide of catecholamine synthesis in isolated bovine adrenal chromaffin cells. Biochem Pharmacol 36, 1551 - 1554 (1987)

14 Houchi H, Masserano JM, Bowyer JF and Weiner N: Regulation of tyrosine hydroxylase activity in pheochromocytoma PC12 cells by bradykinin. Mol Pharmacol 37, 104-110 (1990)

15 Oka M, Isosaki $M$ and Yanagihara N: Isolated bovine adrenal medullary cells: studies on regulation of catecholamine synthesis and release. In Catecholamines: Basic and Clinical Frontiers, Edited by Usdin E, Kopin IJ and Barchas J, pp 70-72, Pergamon Press, Oxford (1979)

16 Matsuoka M: Function and metabolism of catecholamines in the brain. Jpn J Pharmacol 14, 181-193 (1964)

17 Berridge MJ, Downes CP and Hanley MR: Lithium amplifies agonist-dependent phosphatidylinositol response in brain and salivary glands. Biochem J 206, 587-595 (1982)

18 Berridge MJ, Dawson MC, Downes CP and Irvine RF: Changes in the levels of inositol phosphates after agonist-dependent hydrolysis of membrane phosphoinositides. Biochem J 212, 473-482 (1983)

19 Grynkiewicz G, Poenie M and Tsien RY: A new generation of $\mathrm{Ca}^{2+}$ indicators with greatly improved fluorescence properties. J Biol Chem 260, 3440-3450 (1985)

20 Su YF, Cubeddu L and Perkins JP: Regulation of adenosine 3':5'-monophosphate content of human astrocytoma cells. J Cyclic Nucleotide Res 2, 257-270 (1976)

21 Taylor JM and Schimke RT: Synthesis of rat liver albumin in a rabbit reticulocyte cell-free protein-synthesizing. J Biol Chem 248, $7661-7668$ (1973)

22 Yanagihara N, Tank AW and Weiner N: Relationship between activation and phosphorylation of tyrosine hydroxylase by 56 $\mathrm{mM} \mathrm{K}^{+}$in PC-12 cells in culture. Mol Pharmacol 26, 141-147
(1984)

23 Rodriguez-Pena A and Rozengut E: Disappearance of $\mathrm{Ca}^{2-}$-sensitive, phospholipid-dependent protein kinase activity in phorbol ester-treated 3T3 cells. Biochem Biophys Res Commun 120, 1053 - 1059 (1984)

24 Ballester $\mathrm{R}$ and Rosen OM: Fate of immunoprecipitable protein kinase $\mathrm{C}$ in $\mathrm{GH} 3$ cells treated with phorbol 12-myristate 13-acetate. J Biol Chem 260, 15194-15199 (1985)

25 Matthies HJ, Palfrey HC, Hirning LD and Miller RJ: Down regulation of protein kinase $\mathrm{C}$ in neuronal cells. $\mathrm{J}$ Neurosci 7 , $1198-1206$ (1987)

26 Grove DS and Mastro AM: Prevention of the TPA-mediated down-regulation of protein kinase C. Biochem Biophys Res Commun 151, $94-99$ (1988)

27 Berridge MJ and Irvine RF: Inositol trisphosphate a novel second messenger in cellular signal transduction. Nature 312, $315-321$ (1984)

28 Plevin R and Boarder M: Stimulation of formation of inositol phosphates in primary cultures of bovine adrenal chromaffin cells by angiotensin II, histamine, bradykinin and carbachol. J Neurochem 51, 634-641 (1988)

29 Tachikawa E, Tank AW, Yanagihara N, Mosimann W and Weiner N: Phosphorylation of tyrosine hydroxylase on at least three sites in rat pheochromocytoma PC- 12 cells treated with $56 \mathrm{mM} \mathrm{K}^{+}$: determination of the sites on tyrosine hydroxylase phosphorylated by cyclic AMP-dependent and calcium/ calmodulin-dependent protein kinases. Mol Pharmacol 30, 476-485 (1986)

30 Nishizuka Y: Protein kinases in signal transduction. Trends Biochem Sci 9, 163-166 (1986)

31 Nishizuka, Y: The role of protein kinase $C$ in cell surface signal transduction and tumor promotion. Nature 360, 693-698 (1984)

32 Vulliet PR, Woodgett JR, Ferrari S and Hardie DG: Characterization of the sites phosphorylated on tyrosine hydroxylase by $\mathrm{Ca}^{2+}$ and phospholipid-dependent protein kinase, calmodulindependent multiprotein kinase and cyclic AMP-dependent protein kinase. FEBS Lett 182, 335-339 (1985)

33 Yamauchi T, Nakata $\mathbf{H}$ and Fujisawa $\mathbf{H}$ : A new activator protein that activates tryptophan 5-monooxygenase and tyrosine $3-$ monooxygenase in the presence of $\mathrm{Ca}^{2+}$-calmodulin dependent protein kinase. J Biol Chem 256, $5404-5409$ (1981)

34 Haycock JM, Meligeni JA, Bennett WF and Waymire JC: Phosphorylation and activation of tyrosine hydroxylase mediate the acetylcholine-induced increase in catecholamine biosynthesis in adrenal chromaffin cells. J Biol Chem 257, 12641 - 12648 (1982) 